\title{
MAIS ALÉM DO DESAMPARO: ORFANDADE E CHEFIA ENTRE OS BORA NA AMAZÔNIA COLOMBIANA
}

\author{
Maria Luísa Lucas ${ }^{12}$ \\ ${ }^{1}$ Musée du quai Branly - Jacques Chirac, France \\ ${ }^{2}$ Laboratório de Antropologia da Arte, Ritual e Memória, \\ Universidade Federal do Rio de Janeiro, Brasil
}

Vejam: eu estou tão órfão. E por estar tão órfão à floresta não mais irei. [...] Pois o órfão que vai à floresta, o jaguar o rasga com sua pata. (canto aché, in Clastres 1995:81)

Ao perguntar a meus interlocutores Bora quem eram as pessoas vendidas pelos antigos chefes indígenas, eles sempre dizem que se tratava de "orfãozinhos" ou "órfãos". ${ }^{1}$ Desaprovando a conduta de seus antepassados, usam estes termos para se referir àqueles que entre o século XVIII e o começo do XX foram levados por escravagistas luso-brasileiros do baixo CaquetáPutumayo para o médio Solimões, no Brasil. De origem étnica heterogênea, sabe-se que essas pessoas eram à época genericamente designadas como "Miranha". ${ }^{2}$ Em seu relato de viagem no século XIX, Paul Marcoy escreve o seguinte:

Um pai miranha nunca se recusa a trocar seu filho por duas ou três machadinhas, nem a mãe [se recusa a fazê-lo] por meia dúzia de metros de algodão, um colar de miçangas e algumas bugigangas douradas. De tais relações comerciais entre civilização e barbárie resulta o número de jovens Miranha de ambos os sexos que podem ser vistos nas cidades e aldeias da Amazônia, desde Alvarães-Cayçara até Barra do Rio Negro33 (Marcoy 1862:389, trad. minha). 
Comparando o trecho acima com a fala dos Bora atuais, emerge a evidente pergunta: seria possível que as pessoas vendidas fossem, ao mesmo tempo, órfãs e filhas daqueles que as entregavam em troca de ferramentas de metal e outras mercadorias? Parte de meu esforço no que segue será o de demonstrar que ambas as descrições podem ser conciliadas desde que analisemos de maneira mais apurada certas categorias nativas - das quais se destaca, precisamente, aquela de "órfão".

No mundo euro-americano, sabemos que os órfãos evocam certos traços recorrentes. Desde a triste imagem dos órfãos de guerra até os personagens de clássicas fábulas da literatura infantil, os órfãos são no geral vistos como pessoas especialmente dignas de piedade. A compaixão que lhes é dirigida justifica-se em razão do desemparo irreversível no qual se encontram a partir do falecimento de um ou de ambos os pais biológicos na infância. No caso dos Bora, contudo, veremos que a orfandade nem sempre é uma condição irreversível ou estabelecida após a morte dos pais biológicos e, além disso, que os órfãos não são sempre vistos apenas como objetos de compaixão. Para que entendamos melhor o lugar dos órfãos entre os Bora e sua produtividade para que pensemos outros casos ameríndios, é mister que saibamos de antemão sobre a chefia.

\section{Os Bora e a chefia}

Os Bora vivem na região da franja ocidental da Amazônia, no interflúvio do baixo curso dos rios Caquetá e Putumayo. Embora haja comunidades bora no Peru (Razon 1984) e em cidades colombianas como Leticia, este trabalho versa apenas sobre os assentamentos no médio Igaraparaná, na Colômbia. Junto aos Miraña/Miranha, Murui-Muina, Andoque, Muinane, Ocaina, Nonuya e Resígaro, os Bora são uma das etnias da região que se autodenomina como Povo do Centro (ou, em bora, Piinemunáa). Seguem uma tendência patrilocal de residência e se organizam (segundo termos por eles usados em espanhol) em "clãs" divididos em "linhagens" maiores (ou primogênitas) e menores. ${ }^{4}$ Além disso, reconhecem o parentesco bilateralmente, de modo que quaisquer pessoas dos clãs dos pais ou dos avós maternos ou paternos de Ego são tidas como "parentes" (hajki ou meajkímu, "nossa família"). ${ }^{5}$

Bem como ocorre com os demais Povos do Centro, os Bora são conhecidos na literatura histórica e antropológica em razão do genocídio que enfrentaram na virada do século $\mathrm{XX}$, quando os funcionários da empresa de extração de gomas Casa Arana exterminaram grande parte da população 
que vivia na área (Taussig 1987; Casement 2011). Ocupando até o fim do século XIX zonas de terra firme às margens de pequenos igarapés, o intenso e devastador contato com os não indígenas contribuiu para que os Bora paulatinamente migrassem, entre os anos 1930 e 1960, para a várzea do rio Igaraparaná. Apesar dos esforços dos padres capuchinhos (Igualada 1938), os Bora nunca se aglomeraram em grandes aldeias, optando ainda hoje por viverem majoritariamente dispersos ao redor de malocas distribuídas em um vasto território.

Mais do que enormes construções físicas, as malocas bora são unidades residenciais e sociopolíticas cujos nomes são dados de acordo com a prerrogativa ritual de seus chefes ou donos (Guyot 1972). Na grande maioria dos casos, os donos de maloca foram nominados na infância em um ritual prestigioso, ou méméva wahtsì ("ritual-dança para dar nomes"). Eles são ainda os homens primogênitos da linhagem maior de seu clã (Karadimas 1997), detentora de um estoque limitado e invariável de nomes prestigiosos. Enquanto a maioria dos nomes (meme) é simplesmente atribuída aos bebês pelos pais ou outros parentes próximos logo após o nascimento, um homem primogênito de uma linhagem maior recebe, ao longo de sua vida, três nomes: um na infância, um na vida adulta e outro na velhice. ${ }^{6}$ Porém, o recebimento de seu segundo nome implica também a transmissão do anterior a seu próprio filho primogênito. Este tipo de transmissão, portanto, tem como consequência a replicação de um conjunto fechado de três nomes que não variam ao longo das gerações e que se referem ao próprio ancestral do clã. ${ }^{7}$

A importância dos rituais de nominação extrapola, contudo, a simples transmissão onomástica. Nessas ocasiões, ao mesmo tempo em que a criança nominada passa a fazer parte do seleto grupo dos miaáte (traduzidos por meus interlocutores como "nobres" ou "titulares"), seu pai é finalmente reconhecido como o dono da maloca e, por extensão, como ávyéjuúbe, ou o chefe de seu clã. A posição lhe é entregue pelo chefe anterior, seu próprio pai, que se torna assim keéme, ou o ancião desse clã. A transmissão da chefia é consolidada e reconhecida pelos demais na medida em que, deste momento em diante, o novo chefe se sentará sempre no banco principal do mambeadero (Echeverri \& Pereira 2005), palavra em espanhol regional usada para designar o espaço na maloca dos Povos do Centro onde os homens se reúnem todas as noites para conversar, narrar mitos, preparar e consumir coca e tabaco e realizar terapias de cura e profilaxia. O pai do novo chefe, agora keéme ou ancião, ocupará o banco ao lado de seu filho, auxiliando-o sempre que necessário na condução da chefia da maloca. Juntos, eles formarão o núcleo principal de liderança de um clã. 
A palavra em bora para chefe, ávyéjuúbe, é composta por uma raiz (ávyeju) e um sufixo de gênero (-be). Segundo meus interlocutores, ávyeju faz referência ao respeito, ao valor e ao engrandecimento. Assim, um ávyéjuúbe, ou chefe, é um homem alvo de respeito e a quem se atribui grande valor. Ele é tido, além disso, como o intermediário entre seu pessoal e os estrangeiros, estabelecendo relações diplomáticas com o exterior que, no Tempo da Abundância (cf. infra), são marcadas pelo pacifismo e pela "frialdade". Assim, em oposição aos comportamentos "quentes", as condutas frias de um chefe fazem referência a seu comedimento e placidez, ao domínio das terapias com substâncias vegetais, à abstinência sexual e ao respeito às interdições alimentares. Por sua exemplaridade, os chefes são, para os Bora, o modelo ideal das "pessoas verdadeiras" (Londoño Sulkin 2000).

Se bem que seja possível argumentar que a chefia entre os Bora é, como no Alto Xingu (Heckenberger 1996), uma combinação entre hereditariedade e aptidão, é apenas excepcionalmente que pessoas que não vêm de linhagens maiores se tornam chefes de malocas com a prerrogativa de realizar rituais de nominação. ${ }^{8}$ É importante salientar, ademais, que não são reconhecidas como chefes ou ávyéjuúbe pessoas que, eleitas em reuniões comunitárias ou assembleias, ocupam os cargos de liderança que surgiram a partir do contato mais intenso com o mundo não indígena. Elas serão, no máximo, túkevéjtsoóbe ("aquele que organiza"). Entretanto, o termo ávyéjuúbe é utilizado para referir-se a algumas figuras do passado e do presente, como certos comerciantes luso-brasileiros de escravos, exploradores de caucho, narcotraficantes e regatões. Por vezes, os Bora afirmam, em espanhol, que eles são patrones.

A afirmação não significa, porém, que os Bora estabeleçam com esses atores relações de dependência e predação similares àquelas observadas alhures na Amazônia ocidental (por exemplo, Bonilla 2005). Na verdade, o que os Bora indicam com o emprego do termo é que tais patrones são chefes em relação a alguém. Esse modelo de chefia, cuja referência aos patrões parece ser apenas uma de suas variações, extrapola o mundo dos humanos ou da floresta. Assim, quando veem uma manada de queixadas, um cardume de peixes ou um bando de araras que sobrevoa a maloca, é normal que os Bora imediatamente tentem identificar o chefe ou ávyéjuúbe daquele grupo. Ainda, quando uma comitiva de estrangeiros chega a seu território, é comum que busquem rapidamente saber quem é o chefe da equipe. Assim, nesse modelo, todo grupo, seja ele humano ou não humano, depende da existência de um chefe. No geral, os chefes são responsáveis, dentre outras coisas, por gerir e comandar os que estão ao seu redor e que o reconhecem como tal. 
No cotidiano bora, tal incumbência da chefia fica evidente por meio das iniciativas do chefe em organizar trabalhos comunitários, como a abertura de roçados e a limpeza de espaços comuns. Além disso, os chefes são responsáveis pela realização dos rituais, organizando a produção de alimentos, as excursões de pesca e caça e o processamento de coca, tabaco e sal vegetal. Finalmente, eles têm papel central na resolução de conflitos intra ou extrafamiliares, coordenando, se necessário, terapias de proteção e cura. Mesmo no caso de atividades que envolvam agentes externos e lideranças locais, é fundamental que as iniciativas sejam apresentadas, discutidas e consolidadas pelos chefes de clã em reuniões no mambeadero. Contudo, se a efetividade da chefia de um dono de maloca manifesta-se pelo engajamento das pessoas nas atividades por ele coordenadas, a consolidação de seu prestígio no exterior do clã depende de outras variáveis.

Assim, ainda que a chefia seja idealmente dada a partir da ordem de nascimento e do pertencimento às linhagens maiores, a reiteração e o engrandecimento do prestígio de um chefe são construídos de outra forma. Até o começo do século XX, o alcance desse prestígio manifestava-se pelo potencial devorador contido nos artefatos-troféus mantidos nas malocas e obtidos por meio do consumo ritual dos inimigos (Whiffen 1914; Wavrin 1948; Karadimas 1997). Nos dias atuais, quando a antropofagia e a produção de troféus foram descontinuadas, um chefe será tão mais prestigioso quanto maior for sua habilidade em atrair e manter pessoas e relações pacíficas. Naturalmente, espera-se que ele consiga conservar ao seu redor seus irmãos, filhos, netos (ChCh) e sobrinhos (BCh) que, de acordo com a filiação patrilateral, pertencem ao seu clã. Entretanto, ele será reconhecido como um chefe de fato prestigioso e influente caso seja capaz de trazer e conservar perto de si pessoas que, em condições usuais, não viveriam ali. Este é o caso, por exemplo, de parentes por via matrilinear, de pessoas que contrariam o princípio virilocal e, ainda, de quem tem naquela maloca apenas parentes muito distantes ou mesmo nenhuma relação de parentesco prévia. Juntos, eles serão conhecidos como o "pessoal" (múnáajpi) de uma maloca.

Até um passado relativamente recente, os chefes eram chamados por seu pessoal de méécáánií ou "nosso pai" (Karadimas 2000a:601; Guyot 1972). Embora o emprego do termo já não seja corriqueiro, é corrente a ideia de que o pessoal de um chefe seja tsïmene, vocábulo usado para referir-se aos filhos de uma pessoa ou aos filhotes de um animal. Dessa maneira, pertencer ou estar filiado a determinada maloca é algo bem mais abrangente do que apenas viver dentro ou próximo dessas construções: é necessário que se reconheça, no dono da mesma, seu chefe. 
Porém, um pessoal sempre é formado por pessoas que estabelecem diferentes relações com o dono da maloca. Tal heterogeneidade fica evidente quando analisamos a variedade de termos usados tanto nas narrativas míticas quanto nas conversas cotidianas para se falar sobre quem vive ao redor de um chefe. Assim, eles podem ser, além de tsïmene, seus "empregados" (wakiméimúnaájpi, "o pessoal que trabalha"), seus "secretários" (ávyejuúbe nahbebe, "o que é como um irmão do chefe"), seus "clientes", seus "servos" (iicyuwaabe) ou seus "órfãos" (úújóveébe). Antes que categorias ou posições sociais rígidas, estes termos revelam que, em uma maloca, existem diferenças significativas no que diz respeito às relações que cada uma das pessoas mantém com o chefe. Com essas informações em mente, já é possível nos determos na questão da orfandade.

\section{A condição da orfandade}

Embora o tema da orfandade não tenha recebido atenção especial na literatura sobre os povos das Terras Baixas da América do Sul, é comum encontrarmos referências pontuais ao assunto em diversas monografias. Por vezes anedóticas, tais menções costumam abordar a condição de solidão e desproteção daqueles enlutados pela morte de um parente próximo. Em suma, eles "[...] estão sozinhos [...], não possuem parentes" (Gow 2000:47) ou não têm donos (Déléage 2009:118). Ao tratarem diretamente a questão do desamparo, tais referências poderiam nos levar a concluir que, afinal de contas, a orfandade ameríndia não se distancia tanto assim da associação euro-americana entre os órfãos e a compaixão.

Contudo, se dirigimos um olhar mais atento a esses trabalhos, notamos que o desemparo que aflige pessoas em posição de orfandade, mesmo quando associado à carência de alimentos e de termos de parentesco, muitas vezes ultrapassa as relações entre os humanos. Além disso, percebe-se que, embora aludam a uma relação entre pais e filhos, essas referências não necessariamente envolvem pessoas unidas por laços de paternidade biológica (por exemplo, Albert 1985; Taylor 2000; Cesarino 2008). ${ }^{9}$ Assim, considerando que a orfandade ameríndia extrapola tanto as relações entre humanos quanto aquelas entre parentes biológicos, o caso específico dos Bora traz à tona outro ponto crucial: se a chefia idealmente dada pela hereditariedade faz par com a necessária construção da orfandade a partir de uma situação de infortúnio, veremos que a condição dos órfãos pode ser parcialmente revertida por meio de relações que excedem a filiação adotiva comumente 
encontrada nos processos euro-americanos de dissolução ou arrefecimento da orfandade. Guardemos essas informações, que serão importantes para as reflexões seguintes, e nos voltemos novamente ao Caquetá-Putumayo.

Muitos autores que trabalharam entre os Povos do Centro enfatizam, em algum ponto de suas obras, a questão dos órfãos (por exemplo, Gasché 1977; Guyot 1972; Pineda Camacho 2104; Micarelli 2015). Contudo, é comum que façam referência aos mesmos ora como categoria intimamente ligada à posição ocupada no passado pelos cativos de guerra, ora como conceito nativo acionado enquanto metáfora da situação generalizada de desamparo vivida após o genocídio caucheiro. Embora ambas as referências sejam evidentemente pertinentes, penso que elas deixam de fora, ao menos no caso dos Bora, algumas especificidades dos órfãos. Se, como defenderei, os órfãos são fundamentais para que compreendamos a vida social bora, pensar sobre a etimologia do termo entre os Povos do Centro pode nos ajudar.

Entre os Ocaina, Wise (1969) afirma que o radical da palavra para órfão (fuxóóho), ao ser combinado a sufixos de gênero (-ma, -co), forma os vocábulos traduzidos, respectivamente, como viúvo (fuxóónma) e viúva (fuxóónco). Já para os Muinane, a palavra jijovoto é traduzida por Pakky, Walton e Walton (2016) como "órfãos", "maltratados" ou "escravos". Preuss traduz o vocábulo jałenikí, em murui-muina, como "órfão, escravo, servo, pobre" (1994:836, trad. minha). Entre os Bora, o termo úújóveébe também designa tanto a orfandade quanto um estado de empobrecimento. Seu radical, desprovido dos sufixos de gênero, é assim definido por Thiesen e Thiesen: "Uujóve: [...] 1. ser órfão, 2. ser muito pobre" (1998:296, trad. minha). Karadimas, sendo certamente o autor que mais se dedicou a pensar sobre a questão, diz que a palavra para órfão em miraña, í:hóßèébè, pode ser literalmente traduzida como "aquele de quem eu me aproveito" (1997:50, trad. minha). O autor nota, ainda, a proximidade entre este termo e aquele usado para se referir aos sobrinhos (ìhóßèbè). Embora tal coincidência não possa ser facilmente notada no idioma bora, algumas pistas deixadas por Karadimas (2000a; 2000b) nos ajudam a compreender também o nosso caso. Mais especificamente, nos interessa aqui a relação de um chefe com seus sobrinhos (tabyébe), termo que abrange um grande número de pessoas para além dos filhos dos irmãos (ZS e BS). Para fins de compreensão, proponho uma divisão em três categorias voltada exclusivamente aos sobrinhos dos chefes ou donos de maloca.

Assim, em primeiro lugar, temos os filhos dos irmãos (BS) de um chefe. Normalmente todos eles viverão em sua maloca ou ao redor dela e, ainda que não ganhem nomes em rituais de transmissão onomástica, pertencerão ao mesmo clã de seu tio paterno. Serão ainda companheiros do chefe em 
seus afazeres diários, sendo por ele coordenados nos trabalhos nas roças e no mambeadero. Um segundo grupo de sobrinhos, filhos das irmãs dos chefes (ZS), serão filiados ao clã de seus próprios pais e, por viverem em outras malocas, se relacionarão muito pouco com seus tios maternos. Por fim, o terceiro grupo será conformado pelos sobrinhos classificatórios do chefe. Devido a uma abrangente extensão colateral dos termos, o reconhecimento do parentesco entre os Bora faz com que haja uma grande quantidade de pessoas tidas por Ego como seus "primos" ou "primas". ${ }^{10}$ Logo, estando esses parentes em posição análoga à de irmãos e irmãs classificatórios, o número de sobrinhos torna-se igualmente abundante. Vemos um exemplo dessa relação quando observamos, no diagrama abaixo, as pessoas [8] e [12].

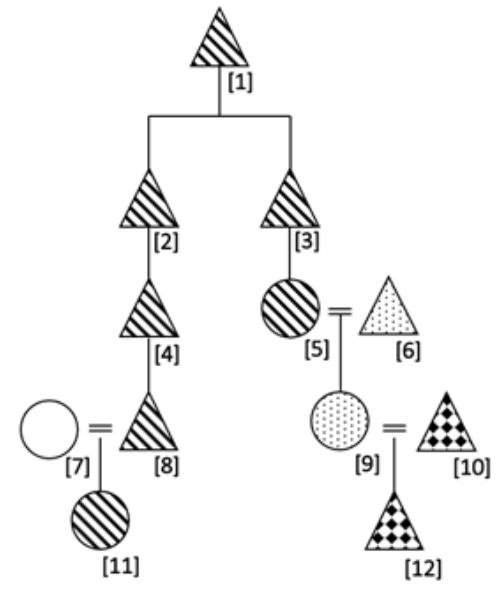

Este diagrama representa de maneira sintética relações que podem ser encontradas em diversas genealogias bora. Os motivos que preenchem cada forma indicam filiações clânicas distintas. Nesse sentido, consideremos que [8] herdou de [1], pela via masculina e através das gerações, a chefia de seu clã. Seguindo as regras de reconhecimento do parentesco, a germanidade entre [2] e [3] gera uma relação de consanguinidade que será percebida até G-2. Dessa maneira, [8] perceberá [5] como sua "tia" (meéu) e [9] como sua "prima" (tsitsíityu nalle). Como vemos, [5] casou-se com [6]. Assumamos que, seguindo a tendência virilocal, ela vive na maloca do clã de seu marido. Consideremos que o mesmo se aplica à sua filha [9], que se casou com [10]. Como [8] e [9] se reconhecem como primos, [12] é, portanto, um sobrinho classificatório de [8]. Ele se encontra, porém, no limite último do reconhecimento do parentesco consanguíneo, algo expresso nas palavras bora por expressões como "ele é meu sobrinho muito distante". Na geração imediatamente seguinte, [11] e [12] já não se verão como parentes. 
Como discuti alhures (Lucas 2019), os Bora não verbalizam nenhuma preferência matrimonial. Ao invés disso, dizem apenas que é interdito "casar-se com parentes". Logo, excluem-se, além das pessoas dos clãs dos avós (ver supra), todos os que se encontram na ampla faixa de reconhecimento colateral do parentesco que abarca pessoas desde uma relação de germanidade real até G-2. Porém, a análise dos casamentos considerados corretos e desejáveis mostra que há um cálculo de "boa distância" na qual o cônjuge ideal é encontrado imediatamente após o limite do reconhecimento do parentesco. ${ }^{11}$ Assim, em consonância com o descrito por Héritier (1981) para o que a autora denominou como sistemas "semicomplexos", o casamento entre [11] e [12] é uma união desejável. A predileção por essa aliança residirá no fato de que ali as pessoas envolvidas não são nem aparentadas demais - evitando-se assim uma união incestuosa - nem demasiadamente distantes a ponto de fazer com que as relações de parentesco existentes até a geração de [8] não possam ser renovadas por meio do estabelecimento de uma nova e diferente aliança.

É preciso ter em mente que um chefe estabelecerá muitas relações do tipo daquela que mantém com [9] dada a extensão colateral da consanguinidade e a consequente proliferação de primos e primas classificatórios. Enquanto chefe, ele buscará atrair para perto de sua maloca pessoas nas posições de primas ([9]), cunhados ([10]) e sobrinhos ([12]) - sobretudo aquelas distantes de suas malocas originais ou filiadas a linhagens menos prestigiosas. Assim, sua filha $\left([11]^{12}\right)$, se vier a se casar com [12] numa união altamente desejável, não se mudará para a maloca do marido, permanecendo ao lado de seu pai. Os filhos dessa união se filiarão provavelmente ao clã do avô materno, aumentando assim o prestígio deste último. Em ambos os casos, teremos sobrinhos classificatórios vivendo temporária ou permanentemente longe de seus chefes ou pais originais e vinculando-se a uma nova maloca (ora como genros, ora simplesmente como filhos das primas ${ }^{13}$ ). Portanto, somos capazes de entender de maneira mais clara a potencial equivalência que Karadimas estabelece entre órfãos e sobrinhos entre os Miraña, bem como sua relevância também para o caso bora.

Proliferam, até aqui, referências bastante heterogêneas em relação à orfandade. Isto acontece porque, como veremos, os órfãos não constituem uma categoria social rígida, ocupando, não raro, posições transitórias e parcialmente reversíveis. Contudo, a aparente instabilidade dessa posição não oblitera sua importância, de modo que podemos afirmar, sinteticamente, que um órfão é uma pessoa que foi privada, definitiva ou provisoriamente, do convívio com seu chefe ou pai original. São ou estão órfãos, portanto: (i) aqueles cujos pais ou chefes de fato morreram; (ii) no passado, cativos de 
guerra que não foram consumidos ritualmente e que passaram a viver junto de seus captores (casando-se ou não com mulheres de sua nova maloca); (iii) sobrinhos classificatórios que residam junto do clã de seu tio materno; (iv) parentes afins de um chefe (sobretudo genros e cunhados) que escapam do princípio virilocal; (v) qualquer outra pessoa que, por alguma razão, se encontre afastada a médio ou longo prazo de sua família paterna. ${ }^{14}$

Se é comum encontrar na literatura americanista pontos de distanciamento entre as relações entre pais e filhos operantes no mundo euro-americano e nos povos indígenas da América do Sul ${ }^{15}$, vale notar que, no caso bora, a posição ocupada pelos órfãos revela como certas relações de parentesco e filiação são diretamente influenciadas pelo lugar dos chefes. Assim, a solidão e o desamparo característicos da orfandade bem podem ser definidos, entre os Bora, pela simples ausência temporária do chefe - e não necessariamente pela morte dos pais. Tendo em mente o caráter potencialmente transitório da orfandade que emerge de minhas afirmações de que esta é uma posição parcialmente reversível, resta-nos indagar como é possível, afinal, modificar tal condição.

\section{As formas da criação}

Já entendemos que, em geral, os chefes se mobilizarão para incorporar órfãos à sua maloca de modo a incrementar seu prestígio. Contudo, a depender do parentesco previamente existente entre eles, distintas relações terão lugar. Dito de outro modo, se nem todos os órfãos são iguais ao olhar daqueles que os acolhem, a maneira com que são acolhidos também é diferente.

Menget (1988:64), baseado em seu trabalho sobre os Ikpeng, propõe uma separação entre adoções "internas" e "externas". Segundo o autor, esta seria a diferença, por exemplo, entre crianças adotadas pela família de seus parentes maternos mais próximos e aquelas capturadas em incursões guerreiras. ${ }^{16}$ Embora dificilmente pessoas vindas do exterior do núcleo familiar sejam incorporadas pela via da consanguinidade entre os Bora, a distinção proposta por Menget nos ajuda a pensar sobre a vinculação dos órfãos a novas malocas. Isto porque, aqui, o contraste interior-proximidade/ exterior-distância - diga-se de passagem, central para a literatura ameríndia (Albert 1985; Viveiros de Castro 1993) - também se mostra importante para que entendamos as diferentes maneiras pelas quais os órfãos bora são "criados". Em poucas palavras, podemos afirmar que quanto mais interna ou próxima for a relação anterior entre o órfão e quem o acolhe, mais provável será a incorporação do primeiro na parentela do segundo por meio da filiação adotiva. 
Este é o caso, por exemplo, de crianças cujo pai faleceu ou daquelas nascidas de uniões que não foram levadas adiante e cujas mães se casaram novamente. Em ambos os casos, essas crianças serão adotadas pelos parentes maternos mais próximos, muitas vezes a contragosto de suas progenitoras. Tais parentes (em geral, avós maternos ou irmãos da mãe) buscarão manter perto de si esses órfãos, aos quais chamarão mepiivyétso. Neste vocábulo, me-é um prefixo pessoal que indica posse direta na primeira pessoa do plural ("nosso"), enquanto o sufixo -tso é um causativo. A raiz piívye, por sua vez, possui um sentido duplo. Segundo meus interlocutores e os missionários do Summer Institute of Linguistics que atuaram no Peru (Thiesen \& Thiesen 1998:236), ela designa "origem, começo, início" ou "a ação de crescer, desenvolver". Daí os religiosos terem, tal qual os padres católicos atuantes na Colômbia, empregado tanto Píivyéébeé ("aquele que cria") quanto Méécáánií ("nosso pai") como traduções para o Deus cristão. Ao fazê-lo, aproveitaram-se do fato de que a raiz piívye abarca os dois sentidos possíveis, traduzidos em espanhol e em português pela palavra "crear/criar". Logo, Deus, ou Píívyéébeé, seria tanto aquele que criou o mundo ex-nihilo quanto aquele que mantém contínua e perenemente seus filhos ou crias.

Assim, as crianças órfãs adotadas são duplamente "criadas" por seus novos parentes. Por um lado, é pelo surgimento dessa relação que os órfãos se inserem definitivamente em uma nova maloca e, a partir da filiação, são criados, isto é, passam a existir plena e socialmente no mundo bora. Por outro, essa nova existência é levada a cabo por meio de um processo constante de "criação" no sentido de "fazer crescer" ou "desenvolver". Tendo em vista as duas acepções do termo, meus interlocutores Bora concordam que essas crianças, mepiivyétso, são ao mesmo tempo "aquelas que nós criamos ou demos origem" e "aquelas que existem por causa de nossa contínua criação". ${ }^{17}$

Sendo a adoção de crianças por parentes próximos algo já descrito nas Terras Baixas da América do Sul (ver, por exemplo, Viegas 2003, Bonilla 2007 e Maizza 2014), é igualmente comum que essa criação passe por relações de nutrição ou feeding, de modo que o ato de alimentar ou "dar de comer" é muitas vezes uma condição para a consolidação do parentesco entre pais e filhos de um modo geral (Costa 2016, 2017; Halbmayer 2004). Nesse sentido, o fornecimento de comida aos órfãos por seus pais adotivos estabeleceria uma relação assimétrica na qual a existência do primeiro depende da ação do segundo. Com todas essas informações em mente notamos que, tal como observou Déléage (2009:118) para o termo ifo entre os Sharanahua, convergem aqui, de um lado, a noção ameríndia de "dono" ou "mestre" e, de outro, as ideias de autoridade, gênese e comensalidade. 
Desta forma, entre os Bora, as crianças órfãs serão alimentadas na primeira infância e, com o tempo, acompanharão seus novos parentes nos labores diários. Os meninos, já crescidos, se sentarão junto a seu chefe no mambeadero, onde poderão se expressar livremente. Mais importante, eles formarão parte do clã de seu pai adotivo, estando filiados de forma definitiva a essa parentela e transmitindo-a a seus descendentes. Entretanto, raramente estarão em pé de igualdade com os filhos primogênitos dos chefes, que são, por seu "assemelhamento" (Guerreiro 2012), verdadeiras replicações potenciais de seus pais. De fato, ainda que os adotados sejam "como filhos legítimos", nas diversas vezes em que perguntei sobre as motivações de um casal (em posição de chefia ou não) para criar uma dessas crianças, a resposta sempre foi algo como "para que nos acompanhe" ou "para que possam trabalhar conosco". À maneira do descrito por Marques Pereira (2002) para os Guarani Kaiowá, é nítido nos trabalhos cotidianos como os órfãos são solicitados mais frequentemente que seus irmãos adotivos. Desse modo, a adoção, apesar de produzir consanguinidade, não apagaria o lastro das relações de parentesco do órfão com seu clã original - e, portanto, sua latente condição de estrangeiro.

Tal condição é ainda mais marcante quando pensamos nas pessoas em posição de orfandade que são incorporadas a uma maloca não pela filiação, mas pela aliança. É o caso, por exemplo, dos genros e cunhados de um chefe que, contrariando a virilocalidade, vivem nas malocas de suas esposas. ${ }^{18}$ É comum que esses maridos das filhas, irmãs, sobrinhas e primas (classificatórias ou não) dos donos de malocas (ou dos homens de seu clã) estejam ali porque pertencem originalmente a malocas de linhagens menores e sem prerrogativas rituais (portanto, menos prestigiosas), ou porque algum infortúnio os tenha privado da convivência com seus chefes. Incluem-se nesse grupo os sobrinhos classificatórios em posições como as que conhecemos anteriormente. Nesses casos, a consanguinidade distante que existe entre eles e seus novos chefes é eclipsada pela possibilidade do casamento com uma mulher de sua maloca atual. Em outras palavras, enquanto possível cônjuge, ele se encontra muito mais próximo dos demais genros e cunhados que ali vivem do que dos netos adotados por seus avós maternos. ${ }^{19}$

Já não sendo crianças, nem se filiando ao clã da maloca que os acolhe, a relação estabelecida entre esses afins e os chefes não será marcada pela alimentação ou feeding. Ao invés disso, é comum que esses homens estabeleçam com seus novos chefes um tipo de serviço da noiva interminável. Assim, eles construirão suas próprias casas ao redor da maloca e abrirão roças para suas esposas, mas serão ao mesmo tempo constante e intensamente solicitados nas tarefas coletivas. As diferenças existentes entre suas 
incumbências e aquelas dos homens do clã de suas esposas ficarão claras durante os encontros noturnos no mambeadero. Ali, apesar de participarem das discussões masculinas, esses homens estarão especialmente ocupados no plantio, na colheita e no processamento da coca e do tabaco consumidos pelos demais participantes.

Assim, se em geral a virilocalidade estabelece entre os Bora uma relação de animosidade e obrigação da nora perante à sogra, a inversão dessa tendência residencial cria um laço entre chefes/sogros/cunhados e órfãos/genros/cunhados similar àquela que encontramos entre um homem e o marido de suas filhas nos povos de terminologia dravidiana nas Guianas (Rivière 1984). Enquanto entre os guianenses tal relação perdura até a morte do sogro e atenua-se com o casamento das filhas do genro (e, portanto, com sua própria transformação em sogro), os órfãos bora serão solicitados pelos chefes-afins enquanto viverem na maloca forasteira. Contudo, tais obrigações serão contrabalanceadas pela comensalidade cotidiana, pelo compartilhamento de coca e tabaco, pela corresidência e pela produção de novas pessoas no seio da maloca, uma vez que são habituais os casos nos quais os filhos dos órfãos-afins traçam sua filiação clânica também por via materna. ${ }^{20}$ Nesse sentido, ainda que as relações de cuidado e proteção do chefe em direção a seus órfãos-afins não passem pela nutrição, elas se tornam evidentes tanto nas afirmações de que tais órfãos fazem parte do "pessoal" daquela maloca quanto nas atividades de cura e profilaxia que lhes são dirigidas em momentos de doença e fragilidade. Todavia, existe ainda um terceiro conjunto de pessoas em posição de orfandade que não se ligam às malocas que os recebem nem pela consanguinidade, nem pelo casamento. Esse era o caso, no passado, dos cativos de guerra.

A incorporação de prisioneiros nos grupos de seus captores pela filiação adotiva ou pela aliança já foi extensamente descrita na literatura amazonista. ${ }^{21}$ No caso dos Bora, porém, mesmo que o matrimônio entre um cativo e uma mulher da maloca captora fosse uma possibilidade, era mais comum que os prisioneiros se tornassem "servos" ou "escravos" (Whiffen 1914:119; Lucas 2019). Nos dias atuais, quando a antropofagia e a captura foram definitivamente interrompidas, não há pessoas que sejam reconhecidas em posições evidentes de servidão. Entretanto, os órfãos que se fixam em uma maloca sem construir ali laços de consanguinidade ou afinidade próximos ocupam um lugar muito específico na dinâmica local.

Durante meu trabalho de campo, conheci alguns desses meninos e meninas. Com uns compartilhei a maloca onde vivi e com outros passei algum tempo ao frequentar casas e comunidades vizinhas. Em diversas ocasiões acompanhei-os em seus muitos afazeres diários nas roças, capoeiras, 
cozinhas e mambeaderos. Sempre atarefados desde o amanhecer até o fim do dia, não participavam ativamente das discussões masculinas noturnas (embora processassem ali a coca e o tabaco), nem eram mencionados quando se falava sobre o "pessoal" de uma maloca. O fato inicialmente me surpreendeu, pois embora se dirijam aos chefes pelo nome, é comum que chamem as esposas desses de "tia" (meéu). Todas as vezes em que busquei entender o emprego do termo, fui informada que o órfão estabelecia com a mulher do chefe relações classificatórias muito distantes, de modo que não era incomum haver dificuldade em retraçá-las com precisão.

Logo percebi também que, no geral, o trabalho que executavam não era retribuído em dinheiro. Segundo os chefes que os acolhiam, ter um lugar onde dormir, compartilhar o alimento com a família anfitriã e ganhar, de vez em quando, roupas, produtos de higiene ou pilhas já era, em si, o próprio pagamento. Mesmo nos casos em que alguma pequena quantia era dada ocasionalmente, os valores oscilavam de tempos em tempos. Do ponto de vista desses órfãos, porém, nunca percebi que este fosse um problema. Ao contrário, apartados de suas famílias e muito atarefados, sempre mencionavam o interesse que tinham em ali permanecer, frequentando assim malocas prestigiosas e grandes rituais. Suas reações às minhas questões sobre os motivos que os mantinham nas malocas estrangeiras suscitam nossa atenção.

Poderíamos supor que o desejo que um órfão tem de vincular-se a um chefe estrangeiro é uma espécie de "servidão voluntária", tal como o conceito foi pensado por La Boétie (2002) em seu esforço de desvendar por que as pessoas obedecem a seus tiranos quando poderiam não o fazer. Baseado na análise da sociedade francesa no século XVI, sua resposta é direta: serve-se porque, no fundo, há vontade de dominar. Dessa maneira, os servos suportariam o mal que sofrem na esperança de eventualmente também terem o aval de exercê-lo. Não penso, contudo, que este seja o caso dos órfãos bora. Com efeito, considero descuidada a interpretação de que, a partir das relações de assimetria aqui descritas, seja possível inferir simplesmente que os Bora formam uma sociedade dividida entre órfãosoprimidos e chefes-opressores.

Noutra direção, penso ser produtivo que nos indaguemos em que medida os órfãos bora veem na incorporação às malocas estrangeiras uma maneira de, na verdade, existirem socialmente de modo pleno. Nesse ponto, é possível que já esteja claro que os Bora não se encaixam facilmente no igualitarismo que domina parte das descrições etnográficas dos sistemas políticos amazônicos, de modo que um órfão se imaginar ou desejar estar numa posição de chefia em uma maloca distinta daquela em que nasceu 
é algo não apenas bastante improvável, mas também inexequível. Isto não significa, porém, que sua condição seja necessariamente irreversível ou que ele esteja fadado a ser subjugado por seu novo chefe. Ao invés disso, concentremo-nos no fato de que experimentar temporária ou permanentemente o infortúnio da orfandade é algo que colocaria em risco sua própria humanidade.

Para os Bora, no caso da morte dos pais, da dissolução do núcleo familiar, da ausência do homem primogênito do clã ou da simples desmobilização do pessoal, um órfão estará, aos olhos dos demais, fora de uma relação de pertencimento suficientemente forte com um chefe e uma maloca. Logo, carentes de relações de parentesco, soltos e sem vínculos, os órfãos correm o risco de se transformarem em alguém sem parentes - e, no limite, em não humanos. ${ }^{22}$ Tanto melhor será se ele for adotado por alguns de seus familiares consanguíneos mais próximos, como seus avós ou tios maternos. Porém, sendo impossível o estabelecimento dessas relações, a incorporação a uma maloca estrangeira, mesmo que sob uma acentuada distância no que diz respeito a seu chefe, garantirá sua existência social e sua humanidade plena ou "verdadeira" (ver infra). Portanto, mesmo quando os órfãos não se relacionam nas malocas que os acolhem por meio de laços de filiação adotiva ou alianças matrimoniais, podemos afirmar que eles são "criados" ou trazidos à existência por causa da relação que estabelecem com seus novos chefes. Para fins de compreensão, vejamos de maneira mais sistematizada essas informações.

\section{Gradiente de orfandade}

Nas reflexões tecidas a partir de seu trabalho entre os Parakanã, Fausto chama a atenção para a existência de duas "modalidades relacionais" que nos interessam aqui (2001:302). Seguindo o raciocínio do autor, podemos dizer que enquanto relações de feeding e proteção (como as que observamos na filiação adotiva de um órfão bora ao clã materno) seriam um tipo de consanguinidade assimétrica, a relação entre sogros e genros (donde o modelo das Guianas lhe serve de inspiração) seria uma forma de afinidade assimétrica. Nesse ponto da exposição, não há dúvidas de que o segundo caso se aplica também às relações entre os órfãos bora e seus chefes-afins. Todavia, estendendo a análise num sentido similar àquele apontado por Grotti e Brightman (2016) no estudo das relações entre os Trio e os Akuriyo, penso que a afinidade assimétrica também pode ser encontrada para além do círculo da aliança matrimonial. ${ }^{23}$ 
Em certo sentido, refletir sobre a afinidade assimétrica fora das relações de aliança ou mesmo sobre a incompletude dos laços de filiação adotiva (tema já tratado, por exemplo, em Halbmayer 2004; Lea 1986; Viegas 2003; Maizza 2014) nos ajuda a entender como, entre os Bora, a produção da assimetria (seja ela consanguínea ou afim) é acompanhada por uma variação da intensidade do controle e da proteção dos chefes em relação aos órfãos. Nesse sentido, penso ser possível falarmos sobre um gradiente de orfandade cujos polos parecem ser, de um lado, o "assemelhamento" e, de outro, a orfandade plena. Vejamos a figura abaixo.

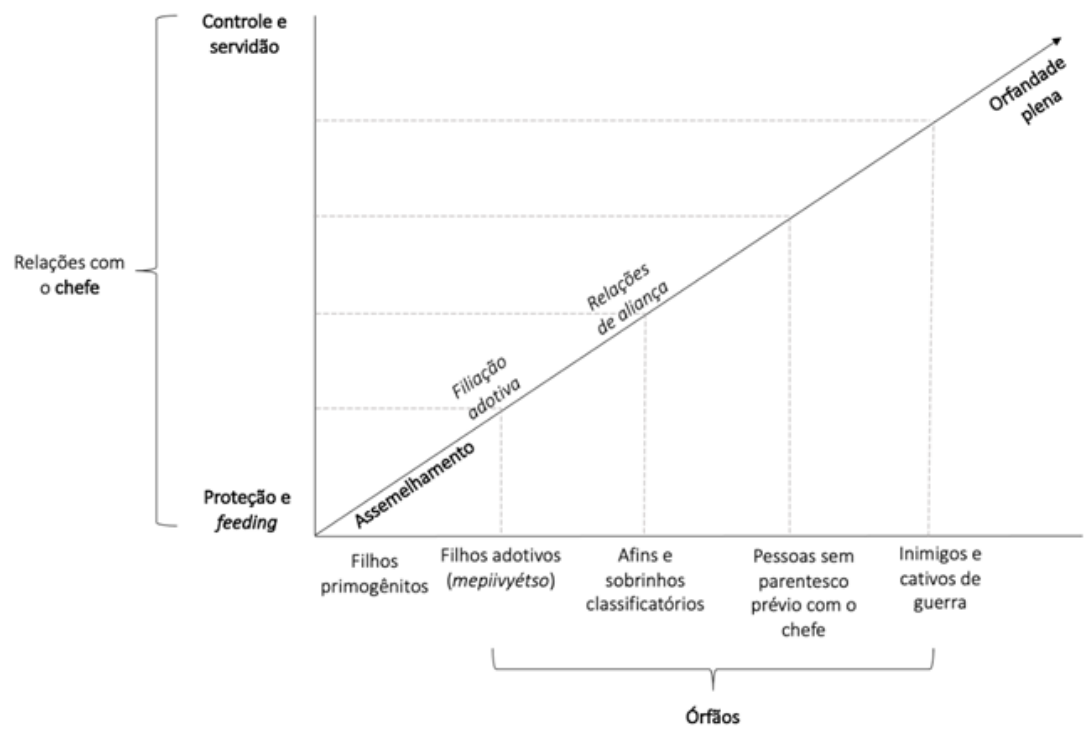

A figura representa graficamente o argumento segundo o qual quanto mais próximo for o parentesco genealógico entre chefe e órfão, maior será a relação de proteção e de alimentação (feeding ou "dar de comer") do primeiro em relação ao segundo. ${ }^{24}$ No outro sentido, quanto menor a proximidade prévia entre eles, mais o relacionamento será marcado por controle e servidão. Observando as posições intermediárias deste gráfico, lembremos que os filhos adotivos do chefe, embora sejam alimentados por seus novos parentes, são consideravelmente mais solicitados que seus irmãos nos trabalhos cotidianos. Por sua vez, os sobrinhos classificatórios e parentes afins masculinos, mesmo que sejam responsáveis por muitos afazeres diários e eventualmente não transmitam sua filiação aos filhos, são cuidados por seus chefes-afins quando se encontram em perigo. Enquanto isso, os órfãos sem relações de parentesco suficientemente próximas na 
maloca acolhedora (donde os cativos eram sua expressão mais radical) encontram na consubstancialidade e na corresidência a frágil contrapartida de sua posição de trabalhadores sobrecarregados pelas constantes demandas dos chefes. Finalmente, mais próximo do polo "proteção e feeding" temos os filhos primogênitos dos donos das malocas. Como vimos, a transmissão intergeracional da chefia faz com que, nesses casos, os filhos se assemelhem a seus pais a ponto de serem suas verdadeiras "replicações" ou "substituições" (Guerreiro 2012:155). No outro extremo, mais próximos das relações de controle e servidão e do estado de orfandade plena, estão os inimigos e os cativos de guerra do passado.

Sei que o uso destes termos (controle e, principalmente, servidão) é pouco comum para se descreverem as relações nas Terras Baixas da América do Sul. ${ }^{25}$ Em primeiro lugar, quando me refiro aqui ao "controle", é importante ter em mente que, em sentido semelhante ao proposto por Fausto (2008), o termo não se refere a um controle do chefe sobre os órfãos que existem como coisas possuídas pelos primeiros. A essa leitura fetichista, oponho minha percepção de que chefe e órfão se relacionam enquanto pessoas que, ao longo do tempo em que convivem no mesmo espaço, estabelecem entre si uma associação na qual o primeiro gere, organiza ou "extrai" as ações cotidianas do segundo. Porém, mais do que uma forma de gerência opressora do chefe em relação à vida dos órfãos, esse controle muitas vezes é, em si, a prerrogativa por meio da qual a instável existência social dos últimos é consolidada.

Por outro lado, como já mencionei, o uso do termo "servidão" acompanha a tradução formulada em espanhol por meus próprios interlocutores. Contudo, pensá-lo como sinônimo para as ideias euro-americanas de privação de liberdade é incorrer em um engano grosseiro (Leach 1967). De maneira geral, os servos (iicyuwaabe) aparecem em inúmeras narrativas míticas, especialmente nas que contam sobre a vida de Garça Branca (Íhchuba, o protótipo do chefe bora) e dos muitos servos que ele mantinha ao seu redor. Porém, se a servidão experimentada pelos cativos de guerra estrangeiros possivelmente se aproximava do descrito por Santos-Granero (2009), as narrativas míticas e as relações assimétricas atuais não apresentam elementos para que pensemos as relações entre chefes e órfãos sem parentesco prévio sob a ótica da formação de grupos servis ou de um sistema de escravidão interna tal como descrito por Jabin (2016) entre os Yuqui.

Assim, ao refletir sobre o fundo de servidão que permeia a relação entre órfãos e chefes, não estaríamos diante da assertiva de que os primeiros, sendo os únicos protagonistas de seus próprios destinos, têm os direitos sobre suas escolhas e suas ações usurpados pelos segundos. A essa associação 
intrínseca e universal entre um indivíduo e sua força de trabalho (Strathern 1988) opõe-se a ideia de que, na verdade, os órfãos utilizam suas relações com os chefes que os acolhem para que possam produzir-se socialmente enquanto pessoas ou humanos plenos. Além disso, quanto maior a distância de parentesco prévio em relação ao novo chefe, mais latente será a possibilidade de que os órfãos simplesmente se destaquem da maloca à qual se vincularam, sendo um bom chefe aquele que tem a capacidade de evitar que isso aconteça ao mesmo tempo em que gerencia os perigos acarretados pela presença estrangeira.

Nota-se, portanto, que os órfãos entre os Bora são vistos de forma ambígua. Via de regra, a compaixão causada por seu desamparo (mais ou mesmo temporário e reversível, a depender do caso) convive com a desconfiança e a cautela geradas por sua posição potencial de não humanidade. Se é comum encontrar menções à relação entre predação e orfandade nas Terras Baixas da América do Sul (Taylor 2000:329; Albert 1985:650), entre os Bora isto é expresso, por exemplo, nas referências genéricas ao comportamento raivoso e "quente" dos órfãos, bem como à sua errância e às suas condutas sexuais repreensíveis. Nesse sentido, a instabilidade inerente à posição dos órfãos deve estar associada a um deslocamento seguro dos mesmos ao longo do gradiente de orfandade que ocupam: ao se associarem a uma nova maloca, eles não devem nem se soltar ou se vingar de seus captores-afins-pais adotivos, nem se equipararem ao chefe e a seus filhos primogênitos.

No limite, portanto, a produção do "assemelhamento" relaciona-se necessariamente à ênfase deliberada na diferença, pois uma maloca habitada pela identidade radical é um mundo impossível e estéril feito apenas de chefes. Por seu turno, a relativa ineficácia ou incompletude da adoção de crianças por seus parentes maternos e da incorporação de cativos aos grupos captores encontraria sua razão de ser na existência de um fundo de servidão e controle que atravessaria todas as relações de orfandade, mas cuja generalização na vida social bora permaneceria igualmente inexequível. Isto porque, de um lado, a proliferação de órfãos próximos ao estado que chamo aqui de "orfandade plena" rapidamente abriria uma perigosa brecha para a prevalência nas malocas de pessoas sem parentes e, portanto, de não humanos. De outro, como costuma acontecer no mundo ameríndio, os próprios laços gerados pela corresidência e pela comensalidade terminam por engendrar relações de cuidado e proteção, mesmo que muito arrefecidas. Assim, o mundo bora ideal não é exclusivamente constituído nem de chefes, nem de órfãos - mas sempre de ambos. Resta-nos indagar, por fim, o que acontece quando não há pessoas capazes de ocupar essas posições. 


\section{As vias da história e o deslocamento da orfandade}

O cataclismo produzido pelos comerciantes da Casa Arana no começo do século XX, conhecido na literatura como "holocausto caucheiro", ocasionou a morte ou a migração forçada de pelo menos $90 \%$ da população bora que vivia no Caquetá-Putumayo (Lucas 2019:72-75). Por sua brutalidade, tal queda demográfica afetou a continuidade da vida social bora em múltiplas esferas, colocando subitamente em risco, por exemplo, malocas, roças, canções, objetos e narrativas míticas. Assim, o "holocausto caucheiro" afetou não apenas o consumo ritual de cativos de guerra, mas também a existência de pessoas em posições de chefia capazes de transmitir ou receber nomes prestigiosos e, no limite, de realizar qualquer tipo de ritual. Em poucas palavras, a orfandade, enquanto condição, generalizou-se. ${ }^{26}$

Nos anos que se seguiram à saída da Casa Arana da região, os Bora buscaram formas de conter a proliferação descontrolada de órfãos. Colocando em prática a reorganização social que aparece em suas narrativas como um processo de "Amanhecer", os Bora fabricaram novos chefes, valendo-se para tanto de um complexo sistema de adoções cerimoniais. ${ }^{27}$ Contudo, a produção de chefes ao longo do século $\mathrm{XX}$, a fundação de novas malocas e o abandono definitivo da antropofagia e da captura de cativos de guerra não extinguiram o que venho denominando como "orfandade plena" da vida social bora. Para entender tal afirmação, conhecer como os Bora concebem sua história recente pode nos ajudar.

Os Bora afirmam que, antes do genocídio, seus antepassados viviam no Tempo dos Animais. Em resumo, o Tempo dos Animais é lembrado, de um lado, pela antropofagia e pelos rituais relacionados à agressividade, à vingança e à guerra. De outro, pela comunicação dos xamãs (ápííchoóbe) com os animais, que auxiliavam os humanos na cura de doenças e nos ataques aos inimigos e lhes davam permissão para a abertura de roças e para expedições de caça e pesca em territórios que lhes pertenciam. Com o fim desse período e com o processo de "Amanhecer", os Bora passaram do Tempo dos Animais para o Tempo da Abundância. Vigorando até os dias atuais, o Tempo da Abundância caracteriza-se pelo fim do canibalismo e de suas práticas associadas, pelos casamentos interétnicos e pela valorização de chefes e rituais pacíficos. Ademais, destaca-se desde então a atuação de xamãs-curandeiros (llúúváábéé) que, por meio de medidas profiláticas e "benzimentos" 28 intermediados pelo tabaco e outras substâncias vegetais, protegem os humanos da ameaça dos animais agressivos - donde a cobra grande e o jaguar ocupam lugar central. ${ }^{29}$ Assim, as relações hostis entre os Bora e seus vizinhos e a comunicação direta com os animais deram 
lugar, no Tempo da Abundância, a relações interétnicas mais pacíficas e a constantes ataques dos animais em direção aos humanos. Tal animosidade é tão notável que podemos afirmar que, se nunca houve morte natural entre os Bora, atualmente o assassino é na grande maioria das vezes um animal. ${ }^{30}$

Contudo, segundo meus interlocutores, não foram os animais que se transformaram radicalmente no Tempo da Abundância, mas sim os xamãs, que atualmente não desejam ou não são capazes de se comunicar com eles. A agressividade latente dos animais, aguçada pela interrupção das relações de troca e reciprocidade que costumavam estabelecer com os humanos, faz com que eles sejam vistos hoje como pessoas inferiores e menos "verdadeiras". É o que relata Londoño Sulkin para os Muinane:

Os Muinane certamente não atribuem uma equivalência moral entre as relações que os animais têm com os membros de sua própria espécie e as relações que as Pessoas Verdadeiras têm entre si. Eles parecem pressupor uma hierarquia moral e ontológica na qual animais se veem e às vezes se pensam como Pessoas Verdadeiras, mas na qual é evidente que eles não são definitivamente humanos (Londoño Sulkin 2005:23, trad. minha).

Bem como os Muinane, os Bora se reconhecem como pessoas "verdadeiras" ou "corretas" (míamúnaa). Contudo, ao contrário da tendência euro-americana de separar humanos e animais a partir de aspectos como "linguagem" ou "consciência", o que diferencia as pessoas verdadeiras dos animais, entre os Bora, é o parentesco - e, por extensão, uma maneira correta de viver e de se relacionar. Assim, no mundo bora, os animais são seres sociais capazes de se reconhecerem como humanos entre si, mas cuja perspectiva seria menos verdadeira na medida em que eles não dominam atributos tipicamente humanos como o comportamento pacífico, o comedimento e a "frialdade". Portanto, foi dessa maneira que a violência e a incompletude dos animais, exacerbadas no Tempo da Abundância, fizeram com que eles se transformassem nos predadores dos humanos por excelência, cabendo às pessoas verdadeiras fazer frente a essas investidas.

Nas narrativas atuais, é comum encontrar afirmações de que no Tempo da Abundância os animais, enquanto espíritos auxiliares dos antigos xamãs, passaram a rondar o exterior da maloca - ao passo que a relação entre chefes e órfãos passou a ser menos marcada pela servidão. Nesse Tempo, cessaram também as negociações com os animais na organização das expedições de caça ou abertura de roçados, hoje precedidas pelo consumo de substâncias vegetais e por terapias de cura. Logo, a "abundância" que caracteriza a época atual refere-se, dentre outros, à produção e ao consumo de alimentos de 
forma adequada e inofensiva. Por meio da utilização de uma série de medidas xamânicas de defesa, profilaxia e "esfriamento", os Bora seriam capazes de, como descreve Vilaça para os Wari', "comerem mais, de tudo, sem medo" (2008:190). Entretanto, enquanto os Wari' se fixaram definitivamente na posição de predadores dos animais, é como se os Bora tivessem empreendido apenas uma parte desse movimento: se para os Wari' os animais já não são humanos (tornando-se no máximo instrumentos para a ação do diabo (:196)), para os Bora os animais são seres daninhos e predadores exatamente porque são pessoas incompletas, inadequadas ou "quentes".

Num momento de extrema crise, é possível que a adoção parcial do discurso cristão (cujas condições podem ser mais bem conhecidas em Lucas [2019]) tenha ajudado os Bora não exatamente a se fixarem na posição de predadores dos animais, mas sim de se colocarem como seus chefes e de estabelecerem com eles uma relação particular de afastamento e assimetria. Retomando os polos relacionais (proteção-feeding/controle-servidão) que incidem nas nuances da relação entre chefes e órfãos, vemos que os Bora, ao serem capazes de exercer controle sobre os animais por meio da defesa e do esfriamento, podem por consequência contar com eles à sua disposição não mais como vetores de ataque aos inimigos, mas enquanto alimentos inofensivos. Dessa maneira, se a humanidade incompleta dos animais se relaciona intimamente com seus comportamentos agressivos e causadores de doenças, não é que os Bora tenham, no Tempo da Abundância, derrotado de uma vez por todas os animais e suprimido do campo das relações aquela posição que venho denominando como "orfandade plena". Dito de outro modo, parece-me simplório imaginar que o próprio modo de vida "quente" do Tempo dos Animais tenha simplesmente desaparecido da vida social bora ao longo do século XX, mesmo que conheçamos tal período apenas por meio das narrativas atuais e das fontes históricas sobre a antropofagia e o xamanismo. Ao invés disso, sempre e quando se valem de maneira contínua de suas substâncias e práticas de proteção, esses mecanismos de defesa permitem que os Bora se fixem na posição de pessoas verdadeiras - e no limite, de chefes de seus animais-servos -, continuando, por outras vias, as relações de assimetria, inimizade e orfandade de outrora.

Nesse processo, os chefes de clã, cuja importância já está evidente, ocupam-se da promoção da pacificidade e da frialdade nas relações entre o pessoal de sua maloca e destes com os animais. Porém, todas as vezes em que os caçadores e os pescadores consomem tabaco antes e durante suas incursões ou que as mulheres partem para suas roças protegidas dos ataques dos animais que por ali vivem ou passeiam, é também como se assistíssemos à replicação ou à atualização da relação entre chefes e órfãos incidindo, 
dessa vez, entre pessoas verdadeiras e animais. Dessa maneira, tudo indica que a chefia e a orfandade podem não ser, entre os Bora, simples posições estáveis de assimetria interna, mas sim os polos de uma grade relacional que dispõe, cria, organiza e dissolve um sem-número de relações.

\section{Conclusão}

Chegamos a um ponto em que já temos elementos suficientes para interpretar a aparente divergência entre a citação que abre este texto (na qual Marcoy afirma que os Povos do Centro vendiam seus próprios filhos) e a afirmação bora de que essas pessoas trocadas por ferramentas de metal eram órfãs. A partir das discussões precedentes, chama-nos a atenção o fato de que não sabemos se Marcoy se referia a filhos biológicos ou adotivos ou, ainda, se o reconhecimento da paternidade era traçado a partir de uma relação de progenitura ou chefia. Se adicionarmos a ausência dessas informações às ideias preconcebidas do próprio viajante sobre as relações de filiação e ao que já conhecemos sobre a abrangência e a idiossincrasia da orfandade na região, entenderemos como é possível que tais pessoas fossem vistas por Marcoy como filhos, ao passo que os indígenas os reconheciam como órfãos. Logo, não é que essas populações estivessem ávidas por vender seus próprios familiares "por duas ou três machadinhas", mas sim que há diferenças importantes nas relações que existem entre um chefe e o pessoal de sua maloca.

Tal conclusão, mesmo que não seja passível de averiguação histórica, vai ao encontro das reflexões tecidas por Karadimas (2000b) a respeito da correspondência supracitada entre órfãos e sobrinhos nos Miraña. Reúnem-se às narrativas atuais, portanto, diversos elementos contra uma interpretação que enxergue a orfandade apenas como uma categoria nativa concebida em reação ao "holocausto caucheiro". De maneira mais abrangente, torna-se manifesto que, apesar das inúmeras investidas sofridas pelos Bora e de tudo o que foi perdido, aniquilado ou transformado, a relação entre chefia e orfandade (e, no limite, a própria existência das malocas) destaca-se tanto por sua persistência e centralidade quanto por ter sido fortemente levada em conta ao longo dos esforços de reorganização social empreendidos no século XX. Nessa direção, compreende-se como o deslocamento das relações de orfandade para o mundo dos animais, associado à produção de novos chefes, permitiu que os Bora mantivessem em seu universo de relações e de possibilidades as ideias de orfandade plena e "assemelhamento".

Enquanto as relações assimétricas e dinâmicas de controle e proteção existentes entre um dono-chefe-pai e seus variados tipos de "filhos" vêm 
sendo minimamente descritas para os campos do xamanismo (presa/espírito familiar) e da guerra e da antropofagia (matador/vítima), o domínio do parentesco humano para além de relações de filiação, adoção ou fosterage carece ainda de investimentos etnográficos mais intensos. A análise que proponho para o caso etnográfico bora indica que o processo de "predação familiarizante" (ou da passagem de uma situação de afinidade simétrica para outra de consanguinidade assimétrica) apresenta-se aqui como um espectro em que se nem sempre o ponto de partida é uma situação de afinidade pura (ou, se quisermos, de inexistência de relações prévias de parentesco), seu lugar de chegada tampouco será o da consolidação absoluta da consanguinidade. Assim, entre os Bora, a assimetria presente na relação entre chefes e órfãos, por sua importância, englobaria as relações de afinidade e consanguinidade, cujas variações operam como uma espécie de termômetro da intensidade das relações de proteção-feeding e controle-servidão.

Dessa maneira, podemos dizer que os netos adotados são como xerimbabos de seus avós maternos apenas se levarmos a sério a incompletude dos processos de adoção e, portanto, do traço inapagável de diferença e afastamento que, no caso analisado, ativa relações de controle e servidão, por menos evidentes que sejam. Num sentido similar, para conceber cativos de guerra ou animais enquanto "afins potenciais" (Viveiros de Castro 2000) é necessário levar em consideração o fato de que a humanidade inferior que experimentam os coloca, desde o ponto de vista dos Bora, numa posição de assimetria inevitável que incide diretamente nas relações que estabelecem com as "pessoas verdadeiras".

Se nos voltarmos ao Caquetá-Putumayo, veremos que, embora haja excelentes etnografias sobre a região, ela não é muito mencionada nos trabalhos que buscaram, nas últimas décadas, propor modelizações abrangentes sobre a Amazônia indígena. Permanece a sensação de que tudo se passa como se os povos dessa área não fossem nem suficientemente andinos, nem genuinamente amazônicos. Em paralelo com uma comparação com as clássicas discussões sobre a guerra e a antropofagia entre povos Tupi-Guarani ou Shuar, pode ser interessante analisar as diferenças e as semelhanças em relação às formas de assimetria no Caquetá-Putumayo e aquelas encontradas, por exemplo, entre os povos do Alto Rio Negro, do Alto Xingu ou do Juruá-Purus. A partir de comparações deste tipo pode ser que percebamos que o Caquetá-Putumayo não diverge tanto assim de outros cenários ameríndios, apresentando apenas manifestações mais ou menos evidentes de modos de relações que se repetem por outras vias nas Terras Baixas da América do Sul. Olhar com mais atenção para os órfãos pode ser uma boa maneira de começar. 
Recebido em 31 de agosto de 2020

Aprovado em 12 de fevereiro de 2021

Maria Luísa Lucas é mestra e doutora em Antropologia Social pelo Museu Nacional/UFRJ. Atualmente é pesquisadora de pós-doutorado no Musée du quai Branly - Jacques Chirac (2019-2022), pesquisadora do Laboratório de Antropologia da Arte, Ritual e Memória (UFRJ) e professora temporária no Departamento de Antropologia da Université Paris Nanterre. Seus principais interesses de pesquisa hoje são as relações assimétricas na Amazônia, a antropologia dos objetos e dos museus e os regimes de historicidade ameríndios. https://orcid.org/0000-0002-0229-2604

E-mail: marialuisalucas@gmail.com

\section{Notas}

1 Este artigo baseia-se em trabalho de campo de aproximadamente quinze meses em comunidades bora no Médio Igaraparaná (Colômbia) e rápidas visitas a assentamentos urbanos na Colômbia e no Peru e a aldeias miranha no médio Solimões (Brasil). Na maior parte do tempo, meus interlocutores se comunicam (comigo e entre si) em espanhol regional. Como ficará evidente, isso faz com que o bilinguismo seja uma característica central da pesquisa. Agradeço imensamente a meus interlocutores Bora, com os quais debati em repetidas ocasiões ao longo dos últimos anos o desenvolvimento da hipótese e a análise dos termos nativos aqui apresentados. Sou grata também aos colegas do LARMe (Museu Nacional, UFRJ) e do EREA (Université Paris Nanterre) pelos valiosos comentários quando da apresentação de versões parciais deste trabalho. Agradeço especialmente a Luiz Costa pela leitura atenciosa.

2 Os Miranha que vivem hoje próximos às cidades amazonenses de Alvarães, Uarini, Fonte Boa e Coari são os descendentes dos indígenas que foram transportados do Caquetá-Putumayo ao Brasil, provavelmente no fim do século XIX e começo do XX (Faulhaber 1996; Arnaud 1974; Lucas 2019).

3 Enquanto "Alvarães-Cayçara" refere-se a onde hoje se encontram os municípios de Tefé e Alvarães, Barra do Rio Negro é o antigo nome da cidade de Manaus. 
4 Os clãs patrilineares são denominados, em bora, pelo vocábulo dóhjiłba, empregado também para designar as tipoias usadas no transporte de bebês. O termo "linhagem", sem correspondentes em bora, é usado aqui porque linaje é como os Bora chamam, em espanhol, os subgrupos que existem dentro de cada clã. Mais numerosas no passado, essas linhagens dividem os clãs em uma linhagem maior (aquela do chefe primogênito, que é também o representante do ancestral do clã) e diversas linhagens menores e de menor prestígio, com chefes não nominados ritualmente. Para uma exposição detalhada desse tipo de sistema, ver Karadimas (1997). Para mais informações sobre o caso bora, ver Lucas (2019).

5 Apesar disso, como ficará evidente, a patrilinearidade e a residência virilocal fazem com que o mundo masculino ocupe um lugar central no cálculo das relações de parentesco genealógico e das possibilidades ou interdições de casamento.

6 Dentre os nomes prestigiosos de pessoas primogênitas, existe ainda uma divisão entre "bonitos" (ími) e "feios" (néhní) algo similar à descrita por Lea (1986) para os Kayapó. No caso bora, enquanto os nomes "bonitos" são transmitidos ao filho e à filha primogênitos de um chefe, o casal de crianças imediatamente mais velho ganha nomes "feios". A oposição bonitos/feios não se aplica aos nomes não prestigiosos. Para mais informações sobre o tema, ver Lucas (2019).

7 Em larga medida, são ainda equivalentes ao que Hugh-Jones (2002:53) descreve como "nomes de espírito" entre os Barasana.

8 Nesses casos, quando o filho primogênito de um dono de maloca se mostra inapto ou desinteressado em assumir as responsabilidades da chefia de seu clã, é comum que essa posição seja transmitida a seu irmão imediatamente mais novo.

9 Observemos, por exemplo, o caso dos espíritos auxiliares e das plantas que, após a morte dos xamãs ou das donas das roças entre Yanomami, são como crianças órfãs que estão sozinhas e têm sede (Albert 1985:186). Em direção semelhante, Taylor (2000:326-327) afirma que, no processo de fabricação de homens "plenamente masculinos", o jovem shuar se dirige ao espectro de um antigo morto como um órfão que fala com seu avô. Esse morto-avô, inicialmente se posicionando como um afim-inimigo de seu "neto", termina por sentir compaixão pelo noviço, como se sua insistência em se colocar como órfão finalmente surtisse efeito. Uma variação desse tema (a dupla condição dos órfãos) pode ser ainda encontrada na constatação de Cesarino (2008:33) de que a pessoa marubo é formada, dentre outros, por um "duplo órfão" associado à solidão, mas antitético à unidade e à exemplaridade dos chefes.

10 Entre outros Povos do Centro (Karadimas 1997; Londoño 2000), a havaianização da terminologia pode ser notada na equivalência entre irmãos e primos, sem distinção entre paralelos e cruzados. Nos Bora, contudo, tal extensão colateral dos termos em G0 sofre algumas inflexões. De maneira resumida, os termos referenciais aplicados aos irmãos e irmãs (nahbe, nalle) encontra variantes entre os primos e primas (tsitsiétyu nahbe, tsitsiétyu nalle). Uma tradução simples destes últimos vocábulos pode ser "um outro tipo enfraquecido de irmão ou irmã". Nas formas vocativas, é comum que primos sejam chamados de dohmi e primas de dohmille. Outra possibilidade é que ambos sejam chamados de naama, sem distinção 
de gênero. O mesmo termo vocativo se aplica, ainda que raramente, aos irmãos e irmãs. Essas correspondências não encontram equivalentes em espanhol, pois não há neste idioma extensão dos termos hermano-hermana para pessoas em posições de primo-prima. Contudo, a mesma distinção desaparece, tanto em bora quanto em espanhol, em G-1. Nessa geração, filhos dos irmãos e irmãs ou filhos dos primos e primas são todos sobrinhos (tabyébe, sobrino) e sobrinhas (taabyélle, sobrina). Para uma discussão mais aprofundada, ver Lucas (2019).

11 No caso das pessoas prestigiosas ou miaáte, soma-se a isso a preferência que incide sobre casamentos entre homens e mulheres que também foram nominados ritualmente e que, portanto, gozam de um status similar.

12 De preferência uma filha não primogênita, sem nomes ou status de prestígio (ver nota anterior).

13 Para um exemplo de sobrinhos envolvidos ora em relações de filiação adotiva, ora de afinidade, ver Bonilla (2007) sobre os Paumari.

14 Nota-se que, aqui, refiro-me sobretudo aos meninos e homens em posições de orfandade. Um estudo da orfandade feminina e suas prováveis inflexões em relação ao caso masculino ainda aguarda esforços etnográficos e analíticos mais intensos. $\mathrm{O}$ tema se torna especialmente interessante quando pensamos que a residência virilocal faz com que as mulheres casadas sejam órfãs por excelência.

15 Ver, por exemplo, o caso da paternidade múltipla (Beckerman \& Valentine 2002).

16 Distinção parecida foi notada por Turner (1966:297) entre os Kayapó.

17 Antes que uma especificidade bora, convergências de sentidos distintos empregados para a noção de "criação" são encontradas, com variações, em outros casos ameríndios. Ver, por exemplo, Jabin (2016:418) e Bonilla (2005:62).

18 Também é possível, aqui, incluir os casos excepcionais em que os sogros vivem junto com suas filhas na maloca de seus genros.

19 A "adoção afim" como uma forma de produção de alianças futuras foi descrita por Halbmayer (2004:158) entre os Yukpa.

20 Nesses casos, porém, o clã paterno também será levando em conta no momento do cálculo de proximidade que identifica os casamentos interditos.

21 Para um resumo dessa discussão, ver Fausto (2001).

22 Aqui, são muitas as semelhanças com o caso guarani-kaiowá tal como descrito por Marques Pereira (2002:185). Segundo Karadimas, entre os Miranha tal condição de não pertencimento seria expressa por meio da ausência de nomes de linhagem (1997:142).

23 Nesses casos, as relações de assimetria estariam marcadas pelo que Grotti e Brightman (2016) denominam como "familiarização parcial" ou "domesticação sem 
assimilação". Eles têm em mente, aqui, o modelo de Fausto (2001) da "predação familiarizante", isto é, da produção de consanguinidade assimétrica a partir da afinidade simétrica, cuja manifestação seria encontrada, por exemplo, na relação de proteção e controle existente entre mestres e xerimbabos - e na qual os primeiros cuidam, alimentam e "extraem ações" dos segundos. É interessante notar que Fausto, no texto em que busca consolidar suas proposições, coloca em relevo exatamente a necessária incompletude dessas relações, indo de certa maneira ao encontro das observações de Grotti e Brightman: "Há um último ponto que gostaria de marcar: a adoção é, por assim dizer, uma filiação incompleta. Ela não produz uma identidade plena, senão uma relação ambivalente, em que o substrato da inimizade é obviado, mas não inteiramente neutralizado" (Fausto 2008:352).

24 Trata-se, grosso modo, de uma constatação muito similar à de Maizza (2014:500) entre os Jarawara.

25 Para exceções, ver, por exemplo, Rivière (1984), Grotti e Brightman (2016) e Santos-Granero (2009).

26 É nesse sentido que os Povos do Centro hoje afirmam ser descendentes dos "órfãos do caucho" (dentre outros, Pineda Camacho 2014; Candre \& Echeverri 1993:151)

27 Embora interessante, a exposição desse sistema extrapola os limites deste trabalho. Para uma análise detalhada, ver Lucas (2019).

28 Cantos-fala de cura e profilaxia similares àqueles descritos entre os povos no Alto Rio Negro (ver, por exemplo, Buchillet 1992).

29 No curso dessas transformações, o papel ocupado pelas plantas cultivadas é outro assunto cujo exame excede o escopo deste artigo.

30 As acusações de feitiçaria entre humanos não desapareceram, mas é bastante comum que tais suspeitas recaiam também sobre os animais. Assim, todos os casos de acusações entre humanos que acompanhei envolviam processos de sedução e convencimento dos malfeitores por parte de animais. 


\section{Referências bibliográficas}

ARNAUD, Expedito. 1974. "Os índios Mirania e a expansão lusobrasileira (Médio Solimões-Japurá, Amazonas)". Boletim do Museu Paraense Emilio Goeldi, nova série Antropologia, 74:1-48.

BECKERMAN, Stephan \& VALENTINE, Paul (eds.). 2002. Cultures of Multiple Fathers: The Theory and Practice of Partible Paternity in Lowland South America. Gainseville: University Press of Florida.

BONILLA, Oiara. 2005. "O bom patrão e o inimigo voraz: predação e comércio na cosmologia Paumari". Mana, 11 (1):41-66.

. 2007. Des proies si désirables: soumission et prédation pour les Paumari d'Amazonie brésilienne. Ph.D. Dissertation, École des Hautes Études en Sciences Sociales.

BUCHILLET, Dominique. 1992. "Nobody is there to hear: Desana therapeutic incantations". In: J. Langdon \& G. Baer (orgs.), Portals of Power: shamanism in South America. Albuquerque: University of New Mexico Press. pp. 211-230.

CANDRE, Hipolito \& ECHEVERRI, Juan Alvaro. 1993. Tabaco frío, coca dulce: Palabras del anciano Kinerai de la Tribu Cananguchal para sanar y alegrar el corazón de sus huérfanos. Jírue diona riérue jííbina: Jikofo Kinéren iéirue jito Kinerai ie jai éniki komeki zuitaja ie jiyóitaja úai yoina. Bogotá: Colcultura.

CASEMENT, Roger. 2011 [1912]. Libro Azul Británico. Informes de Roger Casement y otras cartas sobre las atrocidades en el Putumayo. Lima: CAAAP/IWGIA.

CESARINO, Pedro. 2008. ONISKA. A poética da morte e do mundo entre os Marubo da Amazônia ocidental.
Ph.D. Dissertation, Programa de PósGraduação em Antropologia Social do Museu Nacional/UFRJ.

CLASTRES, Pierre. 1995. Crônica dos índios Guayaki. O que sabem os Aché, caçadores nômades do Paraguai. São Paulo: Editora 34.

COSTA, Luiz. 2016. "Fabricating Necessity. Feeding and Commensality in Western Amazonia". In: M. Brightman; C. Fausto \& V. Grotti (eds.), Ownership and Nurture. Studies in Native Amazonian Property Relations. New York, Oxford: Berghahn. pp. 81-109. . 2017. The Owners of Kinship. Asymmetrical Relations in Indigenous Amazonia. Chicago: HAU Books.

ECHEVERRI, Juan Alvaro \& PEREIRA, Edmundo. 2005. "'Mambear coca não é pintar a boca de verde': Notas sobre a origem e o uso ritual da coca amazônica". In: B. Labate \& S. Goulart (orgs.), O Uso Ritual das Plantas de Poder. Campinas: Ed. Mercado de Letras/Fapesp. pp. 117-185.

FAUlHABER，Priscila. 1996. "A territorialidade Miranha nos rios Japura e Solimões e a fronteira Brasil-Colômbia". Boletim do Museu Paraense Emílio Goeldi, série Antropologia, 12 (2):279-303.

FAUSTO, Carlos. 2001. Inimigos Fiéis: história, guerra e xamanismo na Amazônia. São Paulo: EDUSP. . 2008. "Donos demais: Maestria e domínio na Amazônia". Mana, 14 (2):329-366.

GASCHÉ, Jurg. 1977. "Les fondements de l'organization sociale des indiens witoto et l'illusion exogamique". Actes du XLIIe Congrés International des Americanistes. pp. 141-161. 
GROTTI, Vanessa \& BRIGHTMAN, Marc. 2016. "First Contacts, Slavery and Kinship in North-Eastern Amazonia". In: M. Brightman; C. Fausto \& V. Grotti (eds.), Ownership and Nurture. Studies in Native Amazonian Property Relations. New York, Oxford: Berghahn. pp. 63-80.

GOW, Peter. 2000. "Helpless: the affective preconditions of Piro social life". In: J. Overing \& A. Passes (eds.), The Anthropology of Love and Anger: the Aesthetics of Conviviality in Native Amazonia. Routledge: London. pp. 46-63.

GUERREIRO, Antônio. 2012. Ancestrais e suas sombras: uma etnografia $d a$ chefia kalapalo e seu ritual mortuário. Ph.D. Dissertation, Universidade de Brasília.

GUYOT, Mireille. 1972. "La Maison des Indiens Bora et Miraña". Journal de la Societé des Americanistes, 61:141-176.

HALBMAYER, E. 2004. "'The one who feed has the rights': Adoption and fostering of kin, affines and enemies among the Yukpa and other Caribspeaking Indians of Lowland South America". In: F. Bowie (ed.), CrossCultural Approachs to Adoption. London and New York: Routledge. pp. 145-164.

HECKENBERGER, Michael. 1996. War and Peace in the Shadow of Empire: Sociopolitical Change in the Upper Xingu of Southeastern Amazonia, A.D. 1400-2000. Ph.D. Dissertation, University of Pittsburgh.

HÉRITIER, Françoise. 1981. L'Exercise de la parenté. Paris: Le Seuil-Gallimard.

HUGH-JONES, Stephen. 2002 "Nomes secretos e riqueza visível: nominação no noroeste amazônico". Mana, 8 (2):45-68.

IGUALADA， Bartolomeu. 1938. "Descubrimientos de Nuevas Tribus Indigenas. Tres emocionantes exploraciones misionales em el río Cahuinarí (Intendencia del Amazonas - Colombia)". In: L. Alvarez (ed.), Boletin de Estudios Historicos, v. VII, n. 83. Pasto: Caputxins de Catalunia. JABIN, D. 2016. Le Service éternel: Ethnographie d'un esclavage amérindien (Yuqui, Amazonie bolivienne). Ph.D. Dissertation, Université Paris Nanterre.

KARADIMAS, Dimitri. 1997. Le Corps Sauvage: Idéologie du corps et représentations de l'environnement chez les Miraña d'Amazonie colombienne. Ph.D. Dissertation, Université Paris Nanterre. . 2000a. "Parenté et alliance miraña". L'Homme, 154-155:599-612.

. 2000b. "Parenté en esclavage: Pratiques matrimoniales et aliances politiques chez les Miraña d'Amazonie colombienne". Droit et Cultures, 39:81-100.

LA BOÉTIE, Étienne. 2002. Discours de la servitude volontaire ou le Contr'un. Paris: Payot.

LEA, Vanessa. 1986. Nomes e Nekrets Kayapó: Uma concepção de riqueza. Ph.D. Dissertation, Programa de PósGraduação em Antropologia Social do Museu Nacional/UFRJ.

LEACH, Edmund. 1967. "Caste, class and slavery: the taxonomic problem". In: A. de Reuck \& J. Knight (eds.), Caste and Race: Comparative Approaches. London: Churchill. pp. 5-16.

LONDOÑO SULKIN, Carlos. 2000. The Making of Real People: An Interpretation of a Morality-Centred Theory of Sociality, Livelihood and Selfhood among the Muinane (Colombian Amazon). Ph.D. Dissertation, University of St. Andrews.

. 2005. "Inhuman beings: morality and perspectivism among Muinane people (Colombian Amazon)". Ethnos, 70 (1):7-30. 
LUCAS, Maria Luísa. 2019. O Oriente e o Amanhecer: história, parentesco e ritual entre os Bora na Amazônia Colombiana. Ph.D. Dissertation, Programa de Pós-Graduação em Antropologia Social do Museu Nacional/UFRJ.

MAIZZA, Fabiana. 2014. "Sobre as crianças-planta: o cuidar e o seduzir no parentesco Jarawara". Mana, 20 (3):491-518.

MARCOY, Paul. 1862. Travels in South America: from the Pacific Ocean to the Atlantic Ocean. Vol. II: Tumabuya - Sarayacu - Tierra Blanca - Nauta - Tabatinga - Santa Maria de Belen. New York: Scribner Armstrong \& Co. MARQUES PEREIRA, Levi. 2002. "No mundo dos parentes: a socialização das crianças adotadas entre os Kaiowá". In: A. Silva. A. Macedo \& A. Nunes (orgs.), Crianças indígenas: ensaios antropológicos. São Paulo: Global. pp. 168-186.

MENGET, Patrick. 1988. "Notes sur l'adoption chez les Txicáo du Brésil central". Anthropologie et Sociétés, 12 (2):63-72.

MICARELLI, Giovanna. 2015. “Finding the Taste of Knowledge: The Orphan in Indigenous Epistemologies". Tipiti, 13 (2):74-90.

PAKKY, Clementina; WALTON, James \& WALTON, Janice. 2016. Diccionario Muinane - Español-Inglés. Lima: Instituto Linguistico de Verano.

PINEDA CAMACHO, Roberto. 2014. Los huérfanos de La Vorágine: los andoques y su desafío para superar el llanto del genocidio cauchero. Bogotá: Academia Colombiana de História.

PREUSS, Konrad Theodor. 1994 [19211923]. Religión y mitología de los Uitotos. Bogotá: Editorial Universidad Nacional.
RAZON, Jean-Patrick. 1984. Les Bora et le Caoutchouc: Contribution à l'étude de l'histoire recente des Indiens Bora a l'Amazonie Péruvienne. Master Dissertation, École des Hautes Études en Sciences Sociales.

RIVIĖRE, Peter. 1984. Individual and Society in Guianas: A Comparative Study of Amerindian Social Organisation. Cambridge: Cambridge University Press.

SANTOS GRANERO, Fernando. 2009. Vital Ennemies: slavery, predation, and the Amerindian political economy of life. Texas: University of Texas Press.

STRATHERN, Marilyn. 1988. The Gender of the Gift: Problems with Women and Problems with Society in Melanesia Studies in Melanesian. Berkeley, Los Angeles: University of California Press.

TAUSSIG, Michael. 1987. Shamanism, Colonialism, and the Wild Man: A Study in Terror and Healing. Chicago: University of Chicago Press.

TAYLOR, Anne-Christine. 2000. "Le sexe de la proie: représentations jivaro du lien de parenté". L'Homme, 154155:309-334.

THIESEN, Wesley \& THIESEN, Eva. 1998. Diccionario Bora-Castellano, Castellano-Bora. Lima: Instituto Linguistico de Verano.

TURNER, Terence. 1966. Social Structure and Political Organization among the Northern Kayapó. Ph.D. Dissertation, Harvard University.

VIEGAS, Suzana. 2003. "Eating with your Favourite Mother: Time and Sociality in a Brazilian Amerindian Community". Journal of the Royal Anthropological Institute, 9 (1):21-37.

VILAÇA, Aparecida. 2008. "Conversão, predação e perspectiva". Mana, 14 (1):173-204. 
VIVEIROS DE CASTRO, Eduardo. 1993. "Alguns aspectos da afinidade no dravidianato amazônico". In; M. Carneiro da Cunha \& E. Viveiros de Castro (eds.), Amazônia: etnologia e história indígena. São Paulo: NHIIUSP/FAPESP. pp. 149-210.

. 2000. "Atualização e contraefetuação do virtual na socialidade amazônica: o processo de parentesco". Ilha, 1:546.

WAVRIN, Robert de. 1948. Les Indiens Sauvages de l'Amerique du Sud (Vie Sociale). Paris: Payot.

WHIFFEN, Thomas. 1915. The NorthWest Amazons: notes of some months spent among cannibal tribes. London: Constable.

WISE, M. (ed). 1969. Vocabulario Ocaina. Série Linguistica Peruana. Yarinacocha: Instituto Linguistico de Verano. 
MAIS ALÉM DO DESAMPARO: ORFANDADE E CHEFIA ENTRE OS BORA NA AMAZÔNIA COLOMBIANA

Resumo

O objetivo deste artigo é abordar o tema da orfandade a partir de um estudo com os Bora na região do Caquetá-Putumayo e de possíveis comparações com outros casos etnográficos. Assim, veremos como os órfãos (e, por extensão, os chefes) podem nos ajudar a conhecer algumas relações assimétricas ameríndias encontradas, de maneira bastante abrangente, no domínio do parentesco. Atravessaremos, para isto, questões como a filiação adotiva, a criação de laços de afinidade e as relações de alimentação, de proteção, de controle e de servidão. Ao fazê-lo, paulatinamente colocaremos em xeque a extensão da noção euro-americana de orfandade e sua associação com uma situação irreversível de desamparo. Finalmente, ao conhecermos as transformações dessas relações através do tempo, veremos como os órfãos, ao invés de ocuparem posições sociais rígidas, formam com os chefes os polos de um gradiente relacional que dispõe, cria, organiza e dissolve um sem-número de relações.

Palavras-chave: Amazônia colombiana, Bora, Orfandade, Relações assimétricas.

\section{BEY OND HELPLESSNESS: ORPHANHOOD AND LEADERSHIP AMONG THE BORA OF THE COLOMBIAN AMAZON}

\section{Abstract}

This article discusses orphanhood through an ethnography of the Bora, an Indigenous people of the CaquetáPutumayo region, with comparative incursions into other regions. It shows how orphans (and, by extension, chiefs) can reveal asymmetrical relations that in Amazonia are usually found within the domain of kinship. The article investigates adoptive filiation, the creation of bonds of affinity, and relations of feeding, protection, control, and servitude. In this way, the article questions the Euro-American notion of orphanhood and its association with irreversible helplessness. Finally, by tracing the transformations of these relationships over time, it will show how, far from occupying rigid social positions orphans constitute, with their chiefs, the poles of a relational gradient that creates, organizes, and dissolves a large number of relationships.

Keywords: Colombian Amazonia; Bora; orphanhood; asymmetrical relations. 


\section{MÁS ALLÁ DEL DESAMPARO: \\ HUÉRFANOS Y JEFES ENTRE \\ LOS BORA EN LA AMAZONÍA \\ COLOMBIANA}

\section{Resúmen}

El presente artículo tiene como objetivo discutir la cuestión de la orfandad a partir de la investigación con los Bora, un pueblo indígena de la región de Caquetá-Putumayo, y sus posibles conexiones con otros casos etnográficos. Así, veremos cómo los huérfanos ( $\mathrm{y}$, en cierta medida, los jefes) pueden ayudarnos a conocer algunas relaciones asimétricas amerindias que se encuentran habitualmente en el ámbito del parentesco. Para eso, revisaremos cuestiones como la filiación adoptiva, la creación de lazos de afinidad y las relaciones de alimentación, protección, control y servidumbre. Al hacerlo, gradualmente cuestionaremos la extensión de la noción euroamericana de orfandad y su asociación con una situación de desamparo irreversible. Por último, conociendo las transformaciones de estas relaciones a lo largo del tiempo, plantearemos la hipótesis de que los huérfanos, en lugar de ocupar posiciones sociales rígidas, forman con sus jefes los polos de un gradiente relacional que crea, organiza y disuelve un gran número de relaciones.

Palabras clave: Amazonía colombiana; Bora; orfandad; relaciones asimétricas. 